\title{
EFFECT OF FERTILIZER APPLICATION ON SOIL PROPERTIES AND YIELD OF SESAME (Sesamum indicum L.) VARIETIES IN SOUTHERN GUINEA AND SUDAN SAVANNA AGRO-ECOLOGICAL ZONES OF NIGERIA
}

\author{
Usman M. ${ }^{*}$, Ali A. ${ }^{2}$ and Olatunji O. ${ }^{2}$ \\ ${ }^{1}$ Department of Agricultural Science Education, Federal College of Education \\ (Technical), Potiskum-Nigeria \\ ${ }^{2}$ Department of Soil Science, Federal University of Agriculture, Makurdi-Nigeria \\ *Corresponding Author's Email Address: usmanm2020@gmail.com \\ Tel.: +2348065704224
}

\begin{abstract}
Cite this article: Usman M., Ali A., Olatunji O. (2021), Effect of Fertilizer Application on Soil Properties and Yield of Sesame (sesamum indicum 1.) Varieties in Southern Guinea and Sudan Savanna AgroEcological Zones of Nigeria. African Journal of Agriculture and Food Science, 89-108. DOI: $10.52589 /$ ajafs_SITIW7KB. https://abjournals.org/ajafs/pap ers/volume-4/issue-1/effectof-fertilizer-on-soil-propertiesand-yield-of-sesame-

sesamum-indicum-l-varietiesin-southern-guinea-and-sudansavanna-agro-ecologicalzones-of-nigeria/
\end{abstract}

DOI: 10.52589/ ajafs_SITIW7KB

Received: 31 Jan, 2021

Accepted: 8 March 2021

Published: 19 April 2021

Copyright (C) 2020 The Author(s). This is an Open Access article distributed under the terms of Creative Commons AttributionNonCommercial-

NoDerivatives 4.0 International (CC BY-NC-ND 4.0 ), which permits anyone to share, use, reproduce and redistribute in any medium, provided the original author and source are credited.
ABSTRACT: Field experiments were carried out in 2018 and 2019 cropping seasons to determine the effect of fertilizer application on soil properties and yield of sesame varieties in Southern Guinea and Sudan Savanna Agro-ecological Zones of Nigeria. Treatments consisted of three varieties of sesame (Jigida, NCRIBEN-01M and NCRIBEN-032) and four levels of NPK 15:15:15 fertilizer $\left(0,50,100\right.$ and $\left.150 \mathrm{~kg} \mathrm{ha}^{-1}\right)$. Treatments were laid out in a randomized complete block design (RCBD) and replicated thrice. Prior to planting, surface $(0-15 \mathrm{~cm})$ soil samples were collected from eight points and bulked; post-harvest composite soil samples were also collected on the basis of treatments. All soil samples were analyzed using standard analytical procedures. Data on yield parameters collected include number of capsules per plant, number of seeds per capsule, length of capsule $(\mathrm{cm}), 1000$ capsule weight $(g), 1000$ seeds weight $(g)$ and seed yield $\left(t h a^{-1}\right)$. The crop data generated from the study were subjected to Analysis of Variance (ANOVA) using Genstat Release 10.3 DE after which significant means were separated using Least Significant Difference (LSD) at $5 \%$ level of probability. Results indicated that the soils of both locations were inherently poor in essential plant nutrients. The improved varieties (NCRIBEN-01M and NCRIBEN-032) performed better than the local variety in terms of yields in both cropping seasons. Sesame yield increased with increase in fertilizer application rates up to $150 \mathrm{~kg} \mathrm{ha}^{-1}$. The effect of varieties on soil properties did not differ significantly however, the improved varieties left lower essential nutrients in soil when compared with the local variety. Fertilizer application at $150 \mathrm{~kg} \mathrm{ha}^{-1}$ favoured the retention of organic matter as well as other essential nutrient elements in soil. Location effect showed that the Potiskum soil had more nutrients than that of Makurdi. For sustainable sesame production and maintenance of soil fertility in both locations, application of $150 \mathrm{~kg} \mathrm{ha}^{-1}$ of NPK 15:15:15 to sesame fields is recommended.

KEYWORDS: Sesame Varieties, Fertilizer, Yield, Southern Guinea and Sudan Savanna, Nigeria 


\section{INTRODUCTION}

Sesame (Sesamum indicum L.) is one of the oldest and most important oil seed crops widely grown in tropical and sub-tropical regions around the world and is cultivated for its oil-rich seeds, which grow in pods (NCRI, 2002). Sesame is grown in more than seventy countries worldwide. According to USAID (2002), the United Republic of Tanzania, India, China, Sudan, Nigeria, Myanmar, Burkina Faso and Ethiopia are the greatest sesame producers, respectively covering $70.88 \%$ of the world production. However, the production of sesame in the tropics has lagged behind other crops due to a lack of research, shortage of trained personnel, limited financial support and limited international cooperation. The crop is not dealt with by any of Consultative Group on International Agricultural Research (CGIAR) centers even when the crop has high agronomic importance as it adapts to harsh environments where other oil or food or export crops cannot tolerate (Biswas et al., 2001 and Iwo et al., 2002).

In most tropical countries, the mean yield of sesame is very low (Naturland, 2002) as a result of many production constraints hindering considerable yield improvement. Indeterminate flowering nature and shattering of capsules at maturity, insects, pests and diseases, heat and drought, among other things are the major factors for low yields of sesame (NCRI, 2002). The potential yield of sesame is still much higher than the actual yield, as much damage occurs by pests and diseases, insufficient weed control, to high levels of monocropping, lack of mechanization (amongst others causing seed shattering where not enough labour is available during harvest) and unrealized genetic potential. Potential yields are probably as high as $2000 \mathrm{~kg} \mathrm{ha}^{-1}$ (Adebowale et al., 2010; Hansen, 2011). Eifediyi (2016) stated that other major constraints to sesame production in the tropics are poor road network, poor access to credit facilities, poor extension services, high cost of inorganic fertilizers and other farm inputs.

The importance of fertilizer as agricultural input cannot be over emphasized, particularly in Nigeria where the nutrient levels of the soils are low (Agbede, 2009; Eifediyi, 2016). Fertilizer has been used to improve the yield of sesame for many years especially in the savanna region of Nigeria, where it is a sine- qua-non in fertility management because of the inherently low organic matter content of the soils in the region (Ali et al., 2006). Fertilizer effects on plant growth and yield depend on the crop grown and the environmental conditions that crop encounters. Responses of various crops, including sesame, soybeans, maize, groundnut, wheat and rice to fertilizer application have been studied in Nigeria (Eifediyi et al., 2016 and Ojeniyi et al., 2016) and found to improve crop productivity.

Survey reports by various researchers in the savanna areas revealed that the yield of the sesame crop is low, probably due to lack of improved varieties and poor cultural practices used by farmers. According to Eifediyi et al., (2018), cultivating the crop early in the season predisposes it to vegetative growth and pest invasion. In addition, traditional sesame growers in the study areas rarely use fertilizers to increase the yield. Studies have shown that the crop performs well with the application of inorganic fertilizers (Ojeniyi et al., 2016; Eifediyi et al., 2018) and the use of improved varieties.

Therefore, for sustainable production of sesame, there is a need for adoption of appropriate fertilizer recommendation and improved varieties that would ensure optimum yield. The present study was undertaken to provide documented information on the response of sesame 
varieties and soil properties to fertilizer application with a view to sustaining productivity through appropriate fertilizer application rates across the study agro-ecological zones.

\section{MATERIALS AND METHODS}

\section{Experimental Site}

Field experiments were conducted during 2018 and 2019 cropping seasons at the Teaching and Research Farms of the Federal University of Agriculture, Makurdi, Nigeria and Federal College of Education (Technical), Potiskum, Yobe State, Nigeria to determine the effect of fertilizer application on soil properties and yield of sesame varieties. The Makurdi location falls within the Southern Guinea Savanna Zone of Nigeria with mean rainfall of about 1, 250 $\mathrm{mm}$ per annum and temperature of $25-30{ }^{0} \mathrm{C}$. It is located between latitude $7^{0} 41 \square \mathrm{N}$ to $7^{0}$ $42 \square \mathrm{N}$ and longitude $8^{0} 37 \square \mathrm{E}$ to $8^{0} 38 \square \mathrm{E}$. The Potiskum location falls within the Sudan Savanna Zone of Nigeria with mean rainfall of about $800 \mathrm{~mm}$ per annum and temperature of $39-42{ }^{0} \mathrm{C}$. It is located between latitude $11^{0} 42 \square \mathrm{N}$ to $11^{0} 43 \square \mathrm{N}$ and longitude $11^{0} 04 \square \mathrm{E}$ to $11^{0} 06 \square$ E (YSGN, 2008). The two vegetation zones in Yobe State are Sahel in the North and the Sudan Savanna in the Southern part of the state where Potiskum is located.

Treatments consisted of three varieties of sesame (Jigida, NCRIBEN-01M and NCRIBEN032) and four levels of NPK 15:15:15 fertilizer (0, 50,100 and $\left.150 \mathrm{~kg} \mathrm{ha}^{-1}\right)$. Treatments were laid out in a RCBD with sesame varieties occupying the main plots and fertilizer levels at sub plots and were replicated thrice. The experimental sites at both locations were cleared manually using cutlass and demarcated into experimental units. Thereafter, flat beds and ridges were made using a hoe. NCRIBEN-01M and NCRIBEN-032 (improved varieties) of sesame were sourced from National Cereals Research Institute, Badeggi-Niger State and Jigida (local variety) was sourced from the local farmers. The local variety served as a check at both locations for both cropping seasons.

Sesame seeds were sown at an inter and intra row spacing of $75 \times 5 \mathrm{~cm}$. Sesame seeds were drilled along the ridges (or straight lines on flat land) and thinned to have two plants per stand along the row two weeks after planting (WAP) to give a plant population of 133,333 plants $\mathrm{ha}^{-1}$ (Jakusko and Usman, 2013). This permits maintenance of appropriate plant density and also alleviates the attendant problems associated with high-density planting.

Two hoe weedings at 3 and 9 weeks after planting (WAP) were done during the period of the experiments. Soil mounds were built around the plant stands at each weeding. The fertilizer application was done at 2 WAP by band placement in alternate rows at both locations for both cropping seasons. Crop harvested from the net plots were used for grain yield determination at both locations. Sesame crop was harvested when about $50 \%$ of the capsules turned yellow in colour from green. Harvesting was not delayed in order to prevent seed loss through shattering. Harvesting was done by cutting the stems with sickles. Harvesting by pulling the plants from the root was avoided in order to prevent contamination of seeds with sand. After harvesting, the plants were tied with a rope into bundles and positioned in an erected form on tarpaulin for the capsules to be fully dried. 


\section{Soil Data Collection and Analysis}

Prior to planting for both cropping seasons at both locations, surface $(0-15 \mathrm{~cm})$ soil samples were collected from eight points and bulked; post-harvest composite soil samples were also collected on the basis of treatments. The soil samples taken from each plot according to treatment were air dried, crushed and sieved using $2 \mathrm{~mm}$ sieve and analyzed using standard soil analytical procedures at the Departments of Soil Science, Federal University of Agriculture, Makurdi, Nigeria and University of Maiduguri, Borno State, Nigeria. Particle size distribution was determined by the Hydrometer method (Bouyocous, 1951). Soil pH was measured with the glass electrode $\mathrm{pH}$ meter in soil solution ratio 1: 2 in $0.01 \mathrm{M} \mathrm{CaCl}_{2}$. Soil organic carbon (OC) was determined by the Walkey and Black method. Total $\mathrm{N}$ by the macro-Kjeldahl digestion method (Bremner and Mulraney, 1982), Available $P$ was determined by Bray and Kurtz (1945) extraction method. Exchangeable cations were extracted using $\mathrm{NH}_{4} \mathrm{OAC}$ solution, $\mathrm{K}$ and $\mathrm{Na}$ were read using flame photometer, while $\mathrm{Ca}$ and $\mathrm{Mg}$ was determined using the Atomic Absorption Spectrophotometer (AAS). Effective cation exchange capacity (ECEC) was established as the summation of the exchangeable cations $(\mathrm{K}, \mathrm{Na}, \mathrm{Ca}, \mathrm{Mg}$ ) and exchange acidity. Crop Data Collection and Analysis

Data were collected for the yield parameters of sesame for both cropping seasons at both locations as follows:-

The lengths of ten capsules from each net plot were measured from bottom of the sesame capsule to the capsule apex using a meter rule and the average value recorded. Five plants in the net plot were sampled, the number of capsules on each plant counted and average value determined and recorded. 1000 capsules were taken from ten sampled plants per plot and weighed also on a sensitive Mettler top-loading electronic balance (Model P. 1200), after which the mean weights were recorded. Ten dry capsules were sampled randomly from each net plot. They were split open and the number of seeds in each capsule counted and average values were recorded. A total of 1000 sesame seeds from each plot were counted and weighed on an electronic top-loading Mettler balance to obtain the weight of 1000 seeds. From the seed yield per plot, seed yield per hectare for each plot was computed by converting it into kilogram per hectare by extrapolation.

Data collected for the yield parameters of sesame for both cropping seasons were subjected to the Analysis of Variance (ANOVA) using Genstat Release 10.3 DE after which significant means were separated using Least Significant Difference (LSD) at $5 \%$ level of probability.

\section{RESULTS AND DISCUSSION}

\section{Physical and Chemical Properties of Soil of the Experimental Sites before Planting}

Selected physical and chemical properties of soil of the experimental sites (Table 1) indicate that soils were sandy loam and sandy clay loam in texture for Makurdi and Potiskum sites respectively. This texture is ideal for sesame production as sesame require soils that are well drained for optimum growth and yield. The high sand content of the soils for both seasons respectively (71.8 and $67.10 \%$ ) was indicative of the low clay content which could be attributed to the soil separate sorting activities by organisms, clay eluviation, surface soil 
erosion, parent material or a combination of these factors (Odunze et al., 2006; Malgwi et al., 2008).

The slightly acidic $\mathrm{pH}$ of the soils $(6.08-6.96)$ also indicates that the soils are suitable for sesame production as this $\mathrm{pH}$ range is the optimum $\mathrm{pH}$ for most crops and microbial activities in soil. Bennet (2011) reported that Sesame is intolerant of very acidic or saline soils hence the $\mathrm{pH}$ obtained from these soils is ideal for optimum sesame production. Very low $\mathrm{pH}$ values have a drastic effect on growth, whereas some varieties can tolerate a $\mathrm{pH}$ value up to 8 (Naturland, 2002; Akinoso et al., 2010).

The soils were low in essential plant nutrients and organic carbon $(0.53$ and $0.57 \%)$ with the exception of sodium ( 0.24 and $\left.0.20 \mathrm{cmol} \mathrm{kg}^{-1}\right)$ in Makurdi which was moderate when compared with soil fertility ratings by Esu (1991). The poor nutrient status of this soil is characteristic of many tropical soils where the slash and burn practice coupled with high insolation and rainfall prevent the build-up of organic matter which is the storehouse of most nutrients (Anjembe, 2004). This is in line with earlier observations by Aduayi et al. (2002) and Senjobi et al. (2013) who reported that Nigeria soils are deficient in most nutrients. Other factors responsible for the low nutrient status may include intensive and continuous cropping without corresponding fertilizer application, weathering, and erosion/leaching losses. The low Phosphorus content could be as a result of high $\mathrm{P}$ fixing capacity of most tropical soils (Ibrahim, 2017). The low nutrient status of the soil indicates a high probability of getting a response to the application of fertilizers when the soil is cultivated, otherwise partial or total crop failure is probable.

\section{Main Effects of Varieties and Fertilizer Application on the Yield of Sesame}

The main effects of the sesame varieties and fertilizer Application on the yield of sesame in the 2018 and 2019 cropping season are shown on Table 2. Results indicated that the varieties had significant differences on all the parameters measured with the exception of capsule length and number of seeds per capsules and weight of 1000 seeds. There were significant differences in the varieties with respect to some of the yield attributes such as number of capsules per plant, weight of 1000 capsules and 1000 seeds as well as grain yield as a result of the differences in the varieties and apart from the local variety (jigida), the other varieties have been bred for higher yield and other desirable qualities.

NCRIBEN-01M gave a yield of $0.54 \mathrm{t} \mathrm{ha}^{-1}$ in Makurdi and NCRIBEN-032 gave a yield of $0.87 \mathrm{t} \mathrm{ha}^{-1}$ in Potiskum in 2018. In 2019, the highest yields of 0.44 and $1.38 \mathrm{t} \mathrm{ha}^{-1}$ in Makurdi and Potiskum respectively were obtained with NCRIBEN-032. Ridges produced higher yields followed by flat beds and then zero tillage in both locations. Ridges produced yields of 0.45 and $0.86 \mathrm{t} \mathrm{ha}^{-1}$ in Makurdi and Potiskum respectively in 2018 while in 2019, yields of 0.48 and $1.52 \mathrm{t} \mathrm{ha}^{-1}$ were obtained in Makurdi and Potiskum respectively. Number of capsules and yield of the crop $(24.11,74.70)$ and $\left(0.48,0.87 \mathrm{t} \mathrm{ha}^{-1}\right)$ were higher in the improved varieties than the local variety in both locations. NCRIBEN-032 with yield of 0.54 and $0.87 \mathrm{t} \mathrm{ha}^{-1}$ in Makurdi and Potiskum in 2018 gave significantly higher yield than the other varieties. In 2019, similar results were obtained. All the varieties performed better in Potiskum than Makurdi, and this can be attributed to differences in weather and climate conditions as the elements of climate play vital roles in the type of growth environment available to the crop. Good drainage is crucial, as sesame is very susceptible to short periods of water logging (Bennet, 2011). The soils in Makurdi were waterlogged towards the end of 
August, 2019 and this may be responsible for the low yield obtained there. During each of its development stages, sesame is highly susceptible to water-logging, and can therefore only thrive during moderate rainfall, or when irrigation is carefully controlled in drier regions (Naturland, 2002).

In most tropical countries, the mean yield of sesame is very low (Naturland, 2002) as a result of many production constraints which has hindered considerable yield improvement. Chude et al. (2012) reported that under farmers' conditions beniseed yield is between 200 and 450 $\mathrm{kg} \mathrm{ha}^{-1}$ of dry seed. However, up to $500-800 \mathrm{~kg} \mathrm{ha}^{-1}$ can be obtained by adopting improved practices with a plant population of $25-40,000$ plants $^{-1}$. The yield obtained in the current study in 2018 was in the range of that reported by Chude et al. (2012) and yield of 700 kilograms per hectare reported by Nigeria's Harvest (2009) but in 2019, the yields were higher than those reported here. However, the yields obtained in this study in both years were lower than the $2000 \mathrm{~kg} \mathrm{ha}^{-1}$ reported by Adebowale et al. (2010) and Hassen (2011).

Table 1: Selected Physical and Chemical Properties of Soil of the Experimental Sites before Planting

\begin{tabular}{lccccc}
\hline & \multicolumn{2}{c}{ Makurdi } & \multicolumn{3}{c}{ Potiskum } \\
Property & $\mathbf{2 0 1 8}$ & $\mathbf{2 0 1 9}$ & \multicolumn{2}{c}{$\mathbf{2 0 1 8}$} & $\mathbf{2 0 1 9}$ \\
\hline Chemical Property & & & & \\
pH & 6.08 & 6.50 & 0.96 & 6.70 \\
Organic Carbon (\%) & 0.52 & 0.53 & 1.95 & 0.57 \\
Organic Matter (\%) & 0.90 & 0.91 & 0.17 & 0.19 \\
Total Nitrogen (\%) & 0.11 & 0.12 & 3.15 & 3.30 \\
Available P (mg kg-1) & 3.90 & 4.35 & & \\
Exchangeable Cation (Cmol kg- & & & & \\
1) & & & 3.10 & 2.83 \\
Ca & 3.00 & 2.30 & 2.80 & 2.60 \\
Mg & 2.80 & 2.10 & 0.24 & 0.22 \\
K & 0.27 & 0.31 & 0.03 & 0.02 \\
Na & 0.24 & 0.20 & 6.17 & 5.67 \\
EB & 6.31 & 4.91 & 0.20 & 0.18 \\
EA & 1.10 & 0.90 & 6.37 & 5.85 \\
CEC & 7.41 & 5.81 & & \\
& & & 96.86 & 96.92 \\
Base Saturation (\%) & 85.20 & 84.51 & & \\
Particle Size Distribution & & & 67.10 & 65.00 \\
Sand (\%) & 71.8 & 75.50 & 11.70 & 14.10 \\
Silt (\%) & 10.00 & 9.50 & 21.20 & 20.90 \\
Clay (\%) & 18.20 & 15.00 & Sandy clay loam \\
Textural Class & Sandy loam & &
\end{tabular}


Table 2: Main Effects of Varieties and Fertilizer Application on the Yield of Sesame in 2018

\begin{tabular}{|c|c|c|c|c|c|c|c|c|c|c|c|c|}
\hline \multirow[t]{2}{*}{ Varieties } & \multicolumn{2}{|c|}{$\begin{array}{l}\text { Capsule Length } \\
(\mathrm{cm})\end{array}$} & \multicolumn{2}{|c|}{$\begin{array}{c}\text { No. of capsules } \\
\text { per plant }\end{array}$} & \multicolumn{2}{|c|}{$\begin{array}{l}\text { No. of seeds per } \\
\text { capsule }\end{array}$} & \multicolumn{2}{|c|}{$\begin{array}{l}\text { Weight of } 1000 \\
\text { capsules } \\
(\mathrm{g})\end{array}$} & \multicolumn{2}{|c|}{$\begin{array}{c}\text { Weight of } 1000 \\
\text { seeds } \\
(\mathrm{g})\end{array}$} & \multicolumn{2}{|c|}{$\begin{array}{l}\text { Seed yield } \\
\left(\mathrm{t} \mathrm{ha}^{-1}\right)\end{array}$} \\
\hline & $\begin{array}{c}\text { Makur } \\
\text { di }\end{array}$ & $\begin{array}{c}\text { Potisku } \\
\mathrm{m}\end{array}$ & $\begin{array}{l}\text { Makur } \\
\text { di }\end{array}$ & $\begin{array}{c}\text { Potisku } \\
\mathrm{m}\end{array}$ & $\begin{array}{l}\text { Makur } \\
\text { di }\end{array}$ & $\begin{array}{c}\text { Potisku } \\
\mathrm{m}\end{array}$ & $\begin{array}{l}\text { Makur } \\
\text { di }\end{array}$ & $\begin{array}{l}\text { Potisku } \\
\mathrm{m}\end{array}$ & $\begin{array}{l}\text { Makur } \\
\text { di }\end{array}$ & $\begin{array}{c}\text { Potisku } \\
\mathrm{m}\end{array}$ & $\begin{array}{l}\text { Makur } \\
\text { di }\end{array}$ & $\begin{array}{c}\text { Potisku } \\
\mathrm{m}\end{array}$ \\
\hline V1 & 3.01 & 3.21 & 13.92 & 43.10 & 48.42 & 52.69 & 337.4 & 380.94 & 137.19 & 221.31 & 0.34 & 0.70 \\
\hline $\mathrm{V} 2$ & 3.03 & 3.21 & 17.89 & 65.90 & 59.58 & 52.53 & 379.9 & 401.47 & 136.94 & 220.61 & 0.54 & 0.78 \\
\hline $\mathrm{V} 3$ & 3.03 & 3.20 & 24.11 & 74.70 & 54.94 & 54.92 & 382.5 & 421.72 & 139.69 & 222.92 & 0.48 & 0.87 \\
\hline $\begin{array}{l}\text { LSD } \\
(\mathrm{P} \leq 0.05)\end{array}$ & $\mathrm{NS}$ & $\mathrm{NS}$ & 3.20 & 22.01 & NS & $\mathrm{NS}$ & 17.19 & 15.24 & $\mathrm{NS}$ & 1.63 & 0.10 & 0.05 \\
\hline Fertilizer & & & & & & & & & & & & \\
\hline $\mathrm{F} 1$ & 2.90 & 3.07 & 12.41 & 59.60 & 50.37 & 43.85 & 348.3 & 408.41 & 122.96 & 209.81 & 0.38 & 0.70 \\
\hline $\mathrm{F} 2$ & 3.06 & 3.16 & 13.11 & 66.60 & 54.48 & 50.74 & 361.8 & 417.22 & 133.93 & 215.67 & 0.43 & 0.75 \\
\hline F3 & 2.99 & 3.39 & 14.04 & 73.40 & 57.11 & 56.11 & 389.1 & 424.26 & 143.81 & 224.07 & 0.44 & 0.78 \\
\hline F4 & 3.16 & 3.22 & 16.33 & 90.70 & 60.63 & 62.81 & 420.5 & 435.63 & 151.07 & 236.89 & 0.49 & 0.88 \\
\hline $\begin{array}{l}\mathrm{LSD} \\
(\mathrm{P} \leq 0.05)\end{array}$ & 0.0345 & 0.063 & 0.84 & 6.08 & 1.47 & 2.78 & 8.63 & 3.44 & 4.62 & 4.03 & 0.0162 & 0.03 \\
\hline
\end{tabular}

NS = Not significant, F1 = $0 \mathrm{~kg} \mathrm{ha}^{-1}, \mathrm{~F} 2=50 \mathrm{~kg} \mathrm{ha}^{-1}, \mathrm{~F} 3=100 \mathrm{~kg} \mathrm{ha}^{-1}, \mathrm{~F} 4=150 \mathrm{~kg} \mathrm{ha}^{-1}, \mathrm{~V} 1=$ Jigida, V2 = NCRIBEN-01M, V3= NCRIBEN-032 


\section{Table 3: Main Effects of Varieties and Fertilizer Application on the Yield of Sesame in 2019}

\begin{tabular}{|c|c|c|c|c|c|c|c|c|c|c|c|c|}
\hline \multirow[t]{2}{*}{ Varieties } & \multicolumn{2}{|c|}{$\begin{array}{l}\text { Capsule Length } \\
(\mathrm{cm})\end{array}$} & \multicolumn{2}{|c|}{$\begin{array}{c}\text { No. of capsules } \\
\text { per plant }\end{array}$} & \multicolumn{2}{|c|}{$\begin{array}{l}\text { No. of seeds per } \\
\text { capsule }\end{array}$} & \multicolumn{2}{|c|}{$\begin{array}{l}\text { Weight of } 1000 \\
\text { capsules }(\mathrm{g})\end{array}$} & \multicolumn{2}{|c|}{$\begin{array}{l}\text { Weight of } 1000 \\
\text { seeds }(\mathrm{g})\end{array}$} & \multicolumn{2}{|c|}{$\begin{array}{c}\text { Seed yield } \\
\left(\mathrm{t} \mathrm{ha}^{-1}\right)\end{array}$} \\
\hline & $\begin{array}{c}\text { Makur } \\
\text { di }\end{array}$ & $\begin{array}{c}\text { Potisku } \\
\mathrm{m}\end{array}$ & $\begin{array}{c}\text { Makur } \\
\text { di }\end{array}$ & $\begin{array}{c}\text { Potisku } \\
\mathrm{m}\end{array}$ & $\begin{array}{c}\text { Makur } \\
\text { di }\end{array}$ & $\begin{array}{c}\text { Potisku } \\
\mathrm{m}\end{array}$ & $\begin{array}{l}\text { Makur } \\
\text { di }\end{array}$ & $\begin{array}{c}\text { Potisku } \\
\mathrm{m}\end{array}$ & $\begin{array}{c}\text { Makur } \\
\text { di }\end{array}$ & $\begin{array}{c}\text { Potisku } \\
\mathrm{m}\end{array}$ & $\begin{array}{c}\text { Makur } \\
\text { di }\end{array}$ & $\begin{array}{c}\text { Potisku } \\
\mathrm{m}\end{array}$ \\
\hline V1 & 2.99 & 3.24 & 14.47 & 76.3 & 68 & 58.89 & 370.1 & 424.50 & 135.42 & 226.83 & 0.43 & 1.10 \\
\hline $\mathrm{V} 2$ & 3.01 & 3.23 & 14.67 & 73.9 & 67 & 57.03 & 372.0 & 425.31 & 138.81 & 226.25 & 0.44 & 1.37 \\
\hline V3 & 3.02 & 3.24 & 14.92 & 80.2 & 228 & 60.53 & 375.0 & 425.78 & 140.67 & 228.17 & 0.44 & 1.38 \\
\hline $\operatorname{LSD}(\mathrm{P} \leq 0.05)$ & 0.034 & NS & 0.93 & $\mathrm{NS}$ & $\mathrm{NS}$ & 2.50 & 6.32 & NS & 5.023 & NS & NS & 0.15 \\
\hline \multicolumn{13}{|l|}{ Fertilizer } \\
\hline $\mathrm{F} 1$ & 2.88 & 3.03 & 12.48 & 63.6 & 62 & 48.41 & 344.4 & 409.67 & 121.81 & 213.04 & 0.38 & 1.20 \\
\hline $\mathrm{F} 2$ & 2.99 & 3.16 & 13.59 & 69.2 & 66 & 54.59 & 361.3 & 419.22 & 133.67 & 221.04 & 0.43 & 1.32 \\
\hline F3 & 3.02 & 3.27 & 15.11 & 76.7 & 69 & 60.78 & 377.8 & 428.04 & 142.37 & 230.30 & 0.45 & 1.40 \\
\hline F4 & 3.15 & 3.49 & 17.56 & 97.6 & 288 & 71.48 & 405.9 & 443.85 & 155.33 & 243.96 & 0.49 & 1.57 \\
\hline $\operatorname{LSD}(\mathrm{P} \leq 0.05)$ & NS & 0.06 & $\mathrm{NS}$ & 6.75 & NS & 2.88 & NS & 3.79 & NS & 3.56 & 0.10 & 0.06 \\
\hline
\end{tabular}

NS = Not significant, F1 = $0 \mathrm{~kg} \mathrm{ha}^{-1}, \mathrm{~F} 2=50 \mathrm{~kg} \mathrm{ha}^{-1}, \mathrm{~F} 3=100 \mathrm{~kg} \mathrm{ha}^{-1}, \mathrm{~F} 4=150 \mathrm{~kg} \mathrm{ha}^{-1}, \mathrm{~V} 1=$ Jigida, V2 = NCRIBEN-01M, V3= NCRIBEN-032 
The significant response of yield and yield attributes to fertilizer application is an indication of the role of fertilizers in plant nutrition. Nitrogen, Phosphorus and potassium are the three most limiting of the essential plant nutrient elements and are required in large quantities by crops especially in Nigerian soils with low inherent fertility (Ibrahim et al., 2017). Yield and yield attributes increased with increasing levels of fertilizer application. The present findings are in conformity with the results obtained by Babeji et al. (2006) who reported significant increase in the yield attributes of sesame with increase in Nitrogen fertilizer.

The statuses of nutrients in soils of Nigeria especially those with a history of intensive cultivation are generally low, hence the significant response of sesame yield and its other attributes to fertilizer application. In recent times, many farmers and researchers in Nigeria have used many fertilizer types to improve the yield of sesame, but the yield still remains very low, about $450 \mathrm{~kg} \mathrm{ha}^{-1}$ (Eifediyi et al., 2016), compared to yield in Egypt $\left(1,323 \mathrm{~kg} \mathrm{ha}^{-1}\right.$ ) and Ethiopia (825 kg ha ${ }^{-1}$ ) (FAO, 2009). When soils are continually cultivated, it results in low yields due to the mining of the soil nutrients. This calls for the use of external inputs in order to reverse the loss of nutrients and maintain productivity (Agbede, 2009). The replenishment of nutrients and enhanced quality of tropical soils could be achieved through the addition of fertilizers (Shangakkara et al., 2004). Fertilizer is a component of sustainable crop production systems. Sesame requires adequate supply of nutrients particularly nitrogen, phosphorus and potassium (NPK) for good growth and high yield, hence the response of the sesame crop to fertilizer application in the current study.

Fertilizer application is one major farming operation needed to correct deficiencies in the soil in order to ensure proper growth and functioning of crops with the aim of increasing yield (Srivastava et al., 2006). Adekayode and Ogunkoya (2010) observed improved maize growth parameters with corresponding higher yield in plots treated with fertilizers at 300 and $250 \mathrm{~kg}$ per hectare in Nigeria. The report by Bonsu (2003) that an increase in the level of fertilizer application resulted in an increase in the growth and yield parameters of sesame confirms the current result. Similarly, El-Nakhlawy and Shaheen (2009) stated that vegetative production in plants increases with an increased level of fertilizer and this is in conformity with the results of the current study. Eifediyi et al. (2016) also observed an increase in the number of leaves of sesame when inorganic fertilizer was used in the southern Guinea savanna zone in Nigeria.

Crops require nutrients to perform optimally both in the vegetative and reproductive stages of their life cycle however; most Nigerian soils have been reported to be deficient in these essential nutrients (Ibrahim et al., 2017). Hence, the need for application of external sources for these plant nutrients. For the study under consideration, increase in yield and yield attributes with increasing levels of fertilizer application from the control plots where fertilizer was not applied to plots that received $150 \mathrm{~kg} \mathrm{ha}^{-1}$ of the NPK 15:15:15 was observed.

Responses of various crops, including sesame, soybeans, maize, ground nut, wheat and rice to fertilizer application have been studied in Nigeria (Eifediyi et al., 2016; Ojeniyi et al., 2016). Eifediyi et al. (2016) reported that NPK fertilizer significantly $(\mathrm{p}<0.05)$ influenced the yield of sesame. The results of their study also revealed that NPK fertilizer at the rate of $400 \mathrm{~kg} \mathrm{ha}^{-}$ ${ }^{1}$ and $300 \mathrm{~kg} \mathrm{ha}^{-1}$ produced the highest grain yield of sesame for 2013 and 2014 respectively; these dosage of fertilizer used in obtaining optimum yield were higher than the $150 \mathrm{~kg} \mathrm{ha}^{-1}$ in the present study. Jakusko and Usman (2013) obtained maximum yield of sesame with NPK fertilizer at the rate of $300 \mathrm{~kg} \mathrm{ha}^{-1}$ and $200 \mathrm{~kg} \mathrm{ha}^{-1}$ in 2009 and 2010 respectively. 


\section{Main Effects of Varieties and Fertilizer Application on Soil Properties}

The main effects of varieties and fertilizer application on selected soil properties in 2018 and 2019 are presented on Table 8a-c and 9a-c respectively. The varieties at both locations did not have a significant difference in their effect on most of the soil properties after harvest in 2018 and 2019. The effects of fertilizer on soil properties also show no significant difference in most of the parameters studied at both locations though, most soil parameters increased with increasing levels of fertilizer application. The effects of fertilizer applications on soil physical and chemical properties are important to agricultural sustainability and to increase crop yield (Ayoola, 2006 and Agbede, 2009). The physical and chemical properties of a soil are one of the fundamental factors affecting crop growth, development and yield. This is because these properties have a very high degree of correlation with crop production and have high influence on soil fertility and crop performance (Onwudiwe et al., 2014). For the study under consideration, more focus was on the chemical properties and results revealed that the soil properties were improved with increasing levels of fertilizer application though no significant difference was observed in the interaction effects of most of the soil parameters in both seasons.

Many African soils show nutrient deficiency problems after only a short period of cultivation because of their nature as well as prevailing environmental conditions. Farmers have sought to furnish additional nutrients by the application of chemical fertilizer so that the yields of crops will no longer be limited by the amount of plant nutrients that the natural system can supply (Agber et al., 2012 and Agbede et al., 2013). Fertilizers are usually applied to soil for increasing or maintaining crop yields to meet the increasing demand of food (Olatunji and Ibrahim, 2014; Babbu et al., 2015). Application of inorganic fertilizers results in higher soil organic matter accumulation and biological activity due to increased plant biomass production and organic matter returns to soil in the form of decaying roots, litter and crop residues (Adekiya and Agbede, 2009; Babbu et al., 2015). Addition of soil organic matter enhances soil organic carbon content, which is an important indicator of soil quality and crop productivity (Babbu et al., 2015). Fertilizer additions also affect the chemical composition of soil solution which can be responsible for dispersion/flocculation of clay particles and thus, affects the soil aggregation stability (Haynes and Naidu, 1998).

\section{Effects of Year of Planting and Location on the Yield of Sesame}

The effects of year of planting (Table 4) on sesame yield in Makurdi indicated that yield parameters differed significantly only in the number of capsules, number of seeds per capsule and weight of 1000 capsules but not in the yield per hectare. The non-significant difference in the yield in both years is an indication that the elements of weather and climate did not differ much in those years. However, the effect of year on the yield parameters is pronounced in the Potiskum location and this is probably due to differences in rainfall and temperature in both years in this location (Table 5). 
Table 4: Effect of Year on Yield and Yield Attributes of Sesame in Makurdi

\begin{tabular}{lcccccc}
\hline Year & $\begin{array}{c}\text { Capsule } \\
\text { Length } \\
(\mathrm{cm})\end{array}$ & $\begin{array}{c}\text { No. of } \\
\text { capsules per } \\
\text { plant }\end{array}$ & $\begin{array}{c}\text { No. of } \\
\text { seeds per } \\
\text { capsule }\end{array}$ & $\begin{array}{c}\text { Weight of } \\
1000 \\
\text { capsules }(\mathrm{g})\end{array}$ & $\begin{array}{c}\text { Weight of } \\
1000 \text { seeds } \\
(\mathrm{g})\end{array}$ & $\begin{array}{c}\text { Seed } \\
\text { yield } \\
\left(\mathrm{t} \mathrm{ha}^{-1}\right)\end{array}$ \\
\hline 2018 & 3.008 & 14.69 & 67.51 & 372.34 & 138.30 & 0.436 \\
2019 & 3.024 & 13.97 & 55.65 & 379.94 & 137.94 & 0.436 \\
\hline LSD $(\mathrm{P}<0.05)$ & NS & 0.44 & 1.082 & 3.89 & $\mathrm{NS}$ & $\mathrm{NS}$ \\
\hline
\end{tabular}

Table 5: Effect of Year on Yield and Yield Attributes of Sesame in Potiskum

\begin{tabular}{lcccccc}
\hline Year & $\begin{array}{c}\text { Capsule } \\
\text { Length } \\
(\mathrm{cm})\end{array}$ & $\begin{array}{c}\text { No. of } \\
\text { capsules } \\
\text { per plant }\end{array}$ & $\begin{array}{c}\text { No. of } \\
\text { seeds per } \\
\text { capsule }\end{array}$ & $\begin{array}{c}\text { Weight of } \\
1000 \\
\text { capsules }(\mathrm{g})\end{array}$ & $\begin{array}{c}\text { Weight of } \\
1000 \text { seeds } \\
(\mathrm{g})\end{array}$ & $\begin{array}{c}\text { Seed } \\
\text { yield } \\
\left(\mathrm{t} \mathrm{ha}^{-1}\right)\end{array}$ \\
\hline 2018 & 3.23 & 76.79 & 58.81 & 425.19 & 227.08 & 1.37 \\
2019 & 3.21 & 72.59 & 53.38 & 421.38 & 221.61 & 0.78 \\
\hline LSD $(\mathrm{P}<0.05$ & NS & 3.19 & 1.36 & 1.77 & 1.855 & 0.025 \\
\hline
\end{tabular}

The effect of location indicated that Potiskum yield of $0.79 \mathrm{t} \mathrm{ha}^{-1}$ in 2018 was higher than the $0.44 \mathrm{t} \mathrm{ha}^{-1}$ in Makurdi while in 2019; the Potiskum yield $\left(1.37 \mathrm{t} \mathrm{ha}^{-1}\right)$ was also higher than the $0.44 \mathrm{t} \mathrm{ha}^{-1}$ obtained in Makurdi. The significant difference in the effect of the locations in 2018 could be attributed to the differences in the locations as shown in the soil properties. Yields in Potiskum were higher than Makurdi. Similar trend was obtained in 2019 where yields in Potiskum were significantly and largely higher than what was obtained in Makurdi. Potiskum and the far Northern part of Nigeria are known for large production of sesame in Nigeria (Table 6 and 7).

Table 6: Effect of Location on Yield and Yield Attributes of Sesame in 2018

\begin{tabular}{lcccccc}
\hline Year & $\begin{array}{c}\text { Capsule } \\
\text { Length } \\
(\mathrm{cm})\end{array}$ & $\begin{array}{c}\text { No. of } \\
\text { capsules } \\
\text { per plant }\end{array}$ & $\begin{array}{c}\text { No. of } \\
\text { seeds per } \\
\text { capsule }\end{array}$ & $\begin{array}{c}\text { Weight of } \\
1000 \\
\text { capsules }(\mathrm{g})\end{array}$ & $\begin{array}{c}\text { Weight of } \\
1000 \text { seeds } \\
(\mathrm{g})\end{array}$ & $\begin{array}{c}\text { Seed } \\
\text { yield } \\
\left(\mathrm{t} \mathrm{ha}^{-1}\right)\end{array}$ \\
\hline Makurdi & 3.008 & 14.69 & 67.51 & 372.30 & 138.30 & 0.436 \\
Potiskum & 3.208 & 72.59 & 53.38 & 421.40 & 221.60 & 0.778 \\
\hline LSD $(\mathrm{P}<0.05)$ & 0.055 & 3.796 & 2.48 & 9.14 & 5.38 & 0.029 \\
\hline
\end{tabular}

Table 7: Effect of Location on Yield and Yield Attributes of Sesame in 2019

\begin{tabular}{lcccccc}
\hline Year & $\begin{array}{c}\text { Capsule } \\
\text { Length } \\
(\mathrm{g})\end{array}$ & $\begin{array}{c}\text { No. of } \\
\text { capsules } \\
\text { per plant }\end{array}$ & $\begin{array}{c}\text { No. of } \\
\text { seeds per } \\
\text { capsule }\end{array}$ & $\begin{array}{c}\text { Weight of } \\
1000 \\
\text { capsules }(\mathrm{g})\end{array}$ & $\begin{array}{c}\text { Weight of } \\
1000 \text { seeds } \\
(\mathrm{g})\end{array}$ & $\begin{array}{c}\text { Seed yield } \\
\left(\mathrm{t} \mathrm{ha}^{-1}\right)\end{array}$ \\
\hline Makurdi & 3.02 & 13.97 & 55.65 & 379.90 & 137.90 & 0.436 \\
Potiskum & 3.23 & 76.79 & 58.81 & 425.20 & 227.10 & 1.373 \\
\hline LSD & 0.042 & 2.44 & 1.91 & 11.17 & 4.91 & 0.028 \\
$(\mathrm{P}<0.05)$ & & & & & & \\
\hline
\end{tabular}


Table 8a: Main Effects of Varieties and Fertilizer Application on Selected Soil Properties in 2018

\begin{tabular}{|c|c|c|c|c|c|c|c|c|c|c|c|c|}
\hline \multirow[t]{2}{*}{ Varieties } & \multicolumn{2}{|c|}{$\begin{array}{l}\mathrm{BS} \\
(\%)\end{array}$} & \multicolumn{2}{|c|}{$\begin{array}{c}\mathrm{CEC} \\
\left(\mathrm{cmol} \mathrm{kg}^{-1}\right)\end{array}$} & \multicolumn{2}{|c|}{$\begin{array}{c}\mathrm{Ca} \\
\left(\mathrm{cmol} \mathrm{kg}^{-1}\right)\end{array}$} & \multicolumn{2}{|c|}{$\begin{array}{c}\text { EA } \\
\left(\mathrm{cmol} \mathrm{kg}^{-1}\right)\end{array}$} & \multicolumn{2}{|c|}{$\begin{array}{c}\mathrm{EB} \\
\left(\mathrm{cmol} \mathrm{kg}^{-1}\right)\end{array}$} & \multicolumn{2}{|c|}{$\begin{array}{c}\mathrm{K} \\
\left.(\mathrm{cmol} \mathrm{kg})^{-1}\right)\end{array}$} \\
\hline & $\begin{array}{c}\text { Makur } \\
\text { di }\end{array}$ & $\begin{array}{c}\text { Potisku } \\
\mathrm{m}\end{array}$ & $\begin{array}{c}\text { Makur } \\
\text { di }\end{array}$ & $\begin{array}{c}\text { Potisku } \\
\mathrm{m}\end{array}$ & $\begin{array}{c}\text { Makur } \\
\text { di }\end{array}$ & $\begin{array}{c}\text { Potisku } \\
\mathrm{m}\end{array}$ & $\begin{array}{c}\text { Makur } \\
\text { di }\end{array}$ & $\begin{array}{c}\text { Potisku } \\
\mathrm{m}\end{array}$ & $\begin{array}{c}\text { Makur } \\
\text { di }\end{array}$ & $\begin{array}{c}\text { Potisku } \\
\mathrm{m}\end{array}$ & $\begin{array}{c}\text { Makur } \\
\text { di }\end{array}$ & $\begin{array}{c}\text { Potisku } \\
\mathrm{m}\end{array}$ \\
\hline V1 & 85.26 & 89.12 & 7.81 & 6.31 & 3.14 & 3.46 & 1.15 & 0.45 & 6.63 & 5.85 & 0.28 & 0.26 \\
\hline $\mathrm{V} 2$ & 85.38 & 88.12 & 7.86 & 6.48 & 3.14 & 3.59 & 1.15 & 0.48 & 6.71 & 6.00 & 0.30 & 0.28 \\
\hline V3 & 85.33 & 88.57 & 7.73 & 6.24 & 3.07 & 3.40 & 1.13 & 0.48 & 6.60 & 5.74 & 0.27 & 0.26 \\
\hline $\begin{array}{l}\text { LSD } \\
(\mathrm{P} \leq 0.05)\end{array}$ & 0.73 & NS & 0.49 & $\mathrm{NS}$ & 0.30 & NS & $\mathrm{NS}$ & NS & NS & $\mathrm{NS}$ & NS & NS \\
\hline Fertilizer & & & & & & & & & & & & \\
\hline $\mathrm{F} 1$ & 84.77 & 88.22 & 7.55 & 6.45 & 3.00 & 3.47 & 1.15 & 0.53 & 6.40 & 5.88 & 0.26 & 0.26 \\
\hline $\mathrm{F} 2$ & 85.05 & 88.51 & 7.51 & 6.38 & 2.99 & 3.57 & 1.12 & 0.43 & 6.35 & 5.95 & 0.26 & 0.28 \\
\hline F3 & 85.90 & 88.63 & 8.02 & 6.30 & 3.19 & 3.48 & 1.13 & 0.43 & 6.89 & 5.87 & 0.29 & 0.27 \\
\hline $\mathrm{F} 4$ & 85.57 & 89.06 & 8.12 & 6.24 & 3.27 & 3.41 & 1.17 & 0.49 & 6.95 & 5.74 & 0.33 & 0.26 \\
\hline $\begin{array}{l}\mathrm{LSD} \\
(\mathrm{P} \leq 0.05)\end{array}$ & 0.84 & NS & 0.57 & $\mathrm{NS}$ & 0.35 & $\mathrm{NS}$ & $\mathrm{NS}$ & $\mathrm{NS}$ & 0.34 & $\mathrm{NS}$ & 0.034 & $\mathrm{NS}$ \\
\hline
\end{tabular}

$\mathrm{NS}=$ Not significant, F1 = $0 \mathrm{~kg} \mathrm{ha}^{-1}, \mathrm{~F} 2=50 \mathrm{~kg} \mathrm{ha}^{-1}, \mathrm{~F} 3=100 \mathrm{~kg} \mathrm{ha}^{-1}, \mathrm{~F} 4=150 \mathrm{~kg} \mathrm{ha}^{-1}, \mathrm{~V} 1=$ jigida, V2 = NCRIBEN-01M, V3 = NCRIBEN-032 
Table 8b: Main Effects of Varieties and Fertilizer Application on Selected Soil Properties in 2018

\begin{tabular}{|c|c|c|c|c|c|c|c|c|c|c|c|c|}
\hline \multirow[t]{2}{*}{ Varieties } & \multicolumn{2}{|c|}{$\begin{array}{c}\mathrm{Mg} \\
\left(\mathrm{cmol} \mathrm{kg}^{-1}\right)\end{array}$} & \multicolumn{2}{|c|}{$\begin{array}{c}\mathrm{N} \\
(\%)\end{array}$} & \multicolumn{2}{|c|}{$\begin{array}{c}\mathrm{Na} \\
\left(\mathrm{cmol} \mathrm{kg}^{-1}\right)\end{array}$} & \multicolumn{2}{|c|}{$\begin{array}{l}\mathrm{OC} \\
(\%)\end{array}$} & \multicolumn{2}{|c|}{$\begin{array}{l}\mathrm{OM} \\
(\%)\end{array}$} & \multicolumn{2}{|c|}{$\begin{array}{c}\mathrm{P} \\
\left(\mathrm{mg} \mathrm{kg}^{-1}\right)\end{array}$} \\
\hline & $\begin{array}{c}\text { Makur } \\
\text { di }\end{array}$ & $\begin{array}{c}\text { Potisku } \\
\mathrm{m}\end{array}$ & $\begin{array}{c}\text { Makur } \\
\text { di }\end{array}$ & $\begin{array}{c}\text { Potisku } \\
\mathrm{m}\end{array}$ & $\begin{array}{c}\text { Makur } \\
\text { di }\end{array}$ & $\begin{array}{c}\text { Potisku } \\
\mathrm{m}\end{array}$ & $\begin{array}{c}\text { Makur } \\
\text { di }\end{array}$ & $\begin{array}{c}\text { Potisku } \\
\mathrm{m}\end{array}$ & $\begin{array}{c}\text { Makur } \\
\text { di }\end{array}$ & $\begin{array}{c}\text { Potisku } \\
\mathrm{m}\end{array}$ & $\begin{array}{c}\text { Makur } \\
\text { di }\end{array}$ & $\begin{array}{c}\text { Potisku } \\
\mathrm{m}\end{array}$ \\
\hline V1 & 2.99 & 1.50 & 0.077 & 0.080 & 0.33 & 0.63 & 0.75 & 0.90 & 1.29 & 1.56 & 3.25 & 3.48 \\
\hline V2 & 3.03 & 1.80 & 0.082 & 0.084 & 0.48 & 0.62 & 0.76 & 0.86 & 1.31 & 1.49 & 3.34 & 3.47 \\
\hline V3 & 3.02 & 1.49 & 0.080 & 0.080 & 0.39 & 0.59 & 0.69 & 0.87 & 1.18 & 1.50 & 3.19 & 3.55 \\
\hline $\begin{array}{l}\text { LSD } \\
(\mathrm{P} \leq 0.05)\end{array}$ & $\mathrm{NS}$ & $\mathrm{NS}$ & 0.02 & 0.003 & $\mathrm{NS}$ & $\mathrm{NS}$ & 0.06 & 0.03 & $\mathrm{NS}$ & 0.05 & 0.12 & $\mathrm{NS}$ \\
\hline Fertilizer & & & & & & & & & & & & \\
\hline $\mathrm{F} 1$ & 2.90 & 1.53 & 0.073 & 0.083 & 0.24 & 0.62 & 0.61 & 0.88 & 1.05 & 1.52 & 3.44 & 3.42 \\
\hline $\mathrm{F} 2$ & 2.89 & 1.50 & 0.074 & 0.082 & 0.34 & 0.61 & 0.69 & 0.87 & 1.18 & 1.51 & 3.19 & 3.43 \\
\hline $\mathrm{F} 3$ & 3.16 & 1.88 & 0.083 & 0.081 & 0.56 & 0.62 & 0.80 & 0.88 & 1.38 & 1.52 & 3.68 & 3.68 \\
\hline $\mathrm{F} 4$ & 3.09 & 1.48 & 0.085 & 0.080 & 0.46 & 0.60 & 0.83 & 0.88 & 1.43 & 1.52 & 2.74 & 3.48 \\
\hline $\begin{array}{l}\text { LSD } \\
(\mathrm{P} \leq 0.05)\end{array}$ & $\mathrm{NS}$ & 0.20 & 0.008 & $\mathrm{NS}$ & 0.12 & $\mathrm{NS}$ & 0.11 & $\mathrm{NS}$ & 0.14 & $\mathrm{NS}$ & 0.25 & $\mathrm{NS}$ \\
\hline
\end{tabular}

$\mathrm{NS}=$ Not significant, $\mathrm{F} 1=0 \mathrm{~kg} \mathrm{ha}^{-1}, \mathrm{~F} 2=50 \mathrm{~kg} \mathrm{ha}^{-1}, \mathrm{~F} 3=100 \mathrm{~kg} \mathrm{ha}^{-1}, \mathrm{~F} 4=150 \mathrm{~kg} \mathrm{ha}^{-1}, \mathrm{~V} 1=$ jigida, V2 = NCRIBEN-01M, V3 = NCRIBEN032 
Table 8c: Main Effects of Varieties and Fertilizer Application on Selected Soil Properties in 2018

\begin{tabular}{|c|c|c|c|c|c|c|c|c|}
\hline \multirow[t]{2}{*}{ Varieties } & \multicolumn{2}{|c|}{$\mathrm{pH}$} & \multicolumn{2}{|c|}{$\begin{array}{l}\text { Sand } \\
(\%)\end{array}$} & \multicolumn{2}{|c|}{$\begin{array}{r}\text { Clay } \\
(\%)\end{array}$} & \multicolumn{2}{|c|}{$\begin{array}{l}\text { Silt } \\
(\%)\end{array}$} \\
\hline & Makurdi & Potiskum & Makurdi & Potiskum & Makurdi & Potiskum & Makurdi & Potiskum \\
\hline V1 & 6.13 & 6.61 & 69.16 & 71.72 & 19.08 & 15.37 & 11.76 & 12.92 \\
\hline $\mathrm{V} 2$ & 6.15 & 6.57 & 68.47 & 71.10 & 19.41 & 15.42 & 12.12 & 13.48 \\
\hline V3 & 6.14 & 6.57 & 68.68 & 72.00 & 18.70 & 14.95 & 12.51 & 13.05 \\
\hline $\mathrm{LSD}(\mathrm{P} \leq 0.05)$ & $\mathrm{NS}$ & $\mathrm{NS}$ & NS & NS & NS & NS & NS & NS \\
\hline \multicolumn{9}{|l|}{ Fertilizer } \\
\hline $\mathrm{F} 1$ & 6.07 & 6.55 & 68.46 & 72.02 & 19.28 & 15.06 & 12.11 & 12.92 \\
\hline $\mathrm{F} 2$ & 6.18 & 6.60 & 69.46 & 71.26 & 17.61 & 15.49 & 12.92 & 13.26 \\
\hline F3 & 6.10 & 6.59 & 67.59 & 71.63 & 20.89 & 15.26 & 11.52 & 13.11 \\
\hline F4 & 6.21 & 6.59 & 69.56 & 71.51 & 18.48 & 15.19 & 11.96 & 13.30 \\
\hline $\operatorname{LSD}(\mathrm{P} \leq 0.05)$ & $\mathrm{NS}$ & $\mathrm{NS}$ & NS & $\mathrm{NS}$ & 0.14 & NS & 0.76 & NS \\
\hline
\end{tabular}

NS= Not significant, F1 = $0 \mathrm{~kg} \mathrm{ha}^{-1}, \mathrm{~F} 2=50 \mathrm{~kg} \mathrm{ha}^{-1}, \mathrm{~F} 3=100 \mathrm{~kg} \mathrm{ha}^{-1}, \mathrm{~F} 4=150 \mathrm{~kg} \mathrm{ha}^{-1}$,

V1 = jigida, V2 = NCRIBEN-01M, V3 = NCRIBEN-032 


\section{Table 9a: Main Effects of Varieties and Fertilizer Application on Selected Soil Properties in 2019}

\begin{tabular}{|c|c|c|c|c|c|c|c|c|c|c|c|c|}
\hline \multirow[t]{2}{*}{ Varieties } & \multicolumn{2}{|c|}{$\begin{array}{c}\mathrm{BS} \\
(\%)\end{array}$} & \multicolumn{2}{|c|}{$\begin{array}{c}\mathrm{CEC} \\
\left(\mathrm{cmol} \mathrm{kg}^{-1}\right)\end{array}$} & \multicolumn{2}{|c|}{$\begin{array}{c}\mathrm{Ca} \\
\left(\mathrm{cmol} \mathrm{kg}^{-1}\right)\end{array}$} & \multicolumn{2}{|c|}{$\begin{array}{c}\text { EA } \\
\left(\mathrm{cmol} \mathrm{kg}^{-1}\right)\end{array}$} & \multicolumn{2}{|c|}{$\begin{array}{c}\mathrm{EB} \\
\left(\mathrm{cmol} \mathrm{kg}^{-1}\right)\end{array}$} & \multicolumn{2}{|c|}{$\begin{array}{c}\mathrm{K} \\
\left(\mathrm{cmol} \mathrm{kg}^{-1}\right)\end{array}$} \\
\hline & $\begin{array}{l}\text { Makur } \\
\text { di }\end{array}$ & $\begin{array}{l}\text { Potisku } \\
\mathrm{m}\end{array}$ & $\begin{array}{l}\text { Makur } \\
\text { di }\end{array}$ & $\begin{array}{l}\text { Potisku } \\
\mathrm{m}\end{array}$ & $\begin{array}{l}\text { Makur } \\
\text { di }\end{array}$ & $\begin{array}{l}\text { Potisku } \\
\mathrm{m}\end{array}$ & $\begin{array}{l}\text { Makur } \\
\text { di }\end{array}$ & $\begin{array}{l}\text { Potisku } \\
\mathrm{m}\end{array}$ & $\begin{array}{l}\text { Makur } \\
\text { di }\end{array}$ & $\begin{array}{l}\text { Potisku } \\
\mathrm{m}\end{array}$ & $\begin{array}{l}\text { Makur } \\
\text { di }\end{array}$ & $\begin{array}{c}\text { Potisku } \\
\mathrm{m}\end{array}$ \\
\hline V1 & 84.26 & 92.20 & 7.74 & 6.35 & 3.13 & 3.48 & 1.22 & 0.45 & 6.52 & 5.87 & 0.28 & 0.34 \\
\hline $\mathrm{V} 2$ & 84.28 & 91.39 & 7.61 & 6.58 & 3.07 & 3.61 & 1.19 & 0.56 & 6.41 & 6.02 & 0.28 & 0.28 \\
\hline V3 & 84.20 & 90.62 & 7.74 & 6.34 & 3.14 & 3.44 & 1.22 & 0.58 & 6.52 & 5.71 & 0.29 & 0.26 \\
\hline $\begin{array}{l}\text { LSD } \\
(\mathrm{P} \leq 0.05)\end{array}$ & $\mathrm{NS}$ & $\mathrm{NS}$ & $\mathrm{NS}$ & 0.19 & $\mathrm{NS}$ & 0.17 & $\mathrm{NS}$ & 0.05 & $\mathrm{NS}$ & NS & $\mathrm{NS}$ & NS \\
\hline Fertilizer & & & & & & & & & & & & \\
\hline $\mathrm{F} 1$ & 83.79 & 90.47 & 7.26 & 6.54 & 2.88 & 3.52 & 1.18 & 0.60 & 6.08 & 5.87 & 0.22 & 0.27 \\
\hline $\mathrm{F} 2$ & 83.98 & 91.45 & 7.77 & 6.50 & 3.21 & 3.60 & 1.24 & 0.50 & 6.52 & 5.97 & 0.25 & 0.27 \\
\hline F3 & 84.28 & 92.86 & 7.66 & 6.31 & 3.05 & 3.50 & 1.20 & 0.43 & 6.46 & 5.88 & 0.32 & 0.37 \\
\hline F4 & 84.95 & 90.85 & 8.09 & 6.33 & 3.28 & 3.44 & 1.22 & 0.57 & 6.87 & 5.76 & 0.34 & 0.25 \\
\hline $\begin{array}{l}\text { LSD } \\
(\mathrm{P} \leq 0.05)\end{array}$ & $\mathrm{NS}$ & 1.56 & 0.49 & $\mathrm{NS}$ & 0.30 & $\mathrm{NS}$ & $\mathrm{NS}$ & 0.06 & 0.51 & NS & 0.02 & NS \\
\hline
\end{tabular}

$\mathrm{NS}=$ Not significant, $\mathrm{F} 1=0 \mathrm{~kg} \mathrm{ha}^{-1}, \mathrm{~F} 2=50 \mathrm{~kg} \mathrm{ha}^{-1}, \mathrm{~F} 3=100 \mathrm{~kg} \mathrm{ha}^{-1}, \mathrm{~F} 4=150 \mathrm{~kg} \mathrm{ha}^{-1}, \mathrm{~V} 1=\mathrm{jigida}, \mathrm{V} 2=\mathrm{NCRIBEN}-01 \mathrm{M}, \mathrm{V} 3=\mathrm{NCRIBEN}-$ 032 
Table 9b: Main Effects of Varieties and Fertilizer Application on Selected Soil Properties in 2019

\begin{tabular}{|c|c|c|c|c|c|c|c|c|c|c|c|c|}
\hline \multirow[t]{2}{*}{ Varieties } & \multicolumn{2}{|c|}{$\begin{array}{c}\mathrm{Mg} \\
\left(\mathrm{cmol} \mathrm{kg}^{-1}\right)\end{array}$} & \multicolumn{2}{|c|}{$\begin{array}{l}\mathrm{N} \\
(\%)\end{array}$} & \multicolumn{2}{|c|}{$\begin{array}{c}\mathrm{Na} \\
\left(\mathrm{cmol} \mathrm{kg}^{-1}\right)\end{array}$} & \multicolumn{2}{|c|}{$\begin{array}{l}\mathrm{OC} \\
(\%)\end{array}$} & \multicolumn{2}{|c|}{$\begin{array}{l}\mathrm{OM} \\
(\%)\end{array}$} & \multicolumn{2}{|c|}{$\begin{array}{c}\mathrm{P} \\
\left(\mathrm{mg} \mathrm{kg}^{-1}\right)\end{array}$} \\
\hline & $\begin{array}{c}\text { Makur } \\
\text { di }\end{array}$ & $\begin{array}{l}\text { Potisku } \\
\mathrm{m}\end{array}$ & $\begin{array}{c}\text { Makur } \\
\text { di }\end{array}$ & $\begin{array}{c}\text { Potisku } \\
\mathrm{m}\end{array}$ & $\begin{array}{c}\text { Makur } \\
\text { di }\end{array}$ & $\begin{array}{c}\text { Potisku } \\
\mathrm{m}\end{array}$ & $\begin{array}{c}\text { Makur } \\
\text { di }\end{array}$ & $\begin{array}{c}\text { Potisku } \\
\mathrm{m}\end{array}$ & $\begin{array}{c}\text { Makur } \\
\text { di }\end{array}$ & $\begin{array}{c}\text { Potisku } \\
\mathrm{m}\end{array}$ & $\begin{array}{c}\text { Makur } \\
\text { di }\end{array}$ & $\begin{array}{c}\text { Potisku } \\
\mathrm{m}\end{array}$ \\
\hline V1 & 2.87 & 1.50 & 0.077 & 0.082 & 0.24 & 0.63 & 0.62 & 0.90 & 1.07 & 1.56 & 3.64 & 3.49 \\
\hline V2 & 2.83 & 1.52 & 0.073 & 0.085 & 0.24 & 0.61 & 0.57 & 0.86 & 0.98 & 1.48 & 3.55 & 3.48 \\
\hline V3 & 2.87 & 1.49 & 0.077 & 0.079 & 0.24 & 0.58 & 0.62 & 0.87 & 1.06 & 1.50 & 3.69 & 3.56 \\
\hline $\mathrm{LSD}(\mathrm{P} \leq 0.05)$ & $\mathrm{NS}$ & $\mathrm{NS}$ & $\mathrm{NS}$ & 0.004 & $\mathrm{NS}$ & $\mathrm{NS}$ & $\mathrm{NS}$ & $\mathrm{NS}$ & $\mathrm{NS}$ & $\mathrm{NS}$ & $\mathrm{NS}$ & NS \\
\hline Fertilizer & & & & & & & & & & & & \\
\hline $\mathrm{F} 1$ & 2.77 & 1.53 & 0.053 & 0.083 & 0.21 & 0.62 & 0.66 & 0.87 & 1.14 & 1.51 & 2.50 & 3.44 \\
\hline $\mathrm{F} 2$ & 2.84 & 1.50 & 0.063 & 0.081 & 0.23 & 0.60 & 0.43 & 0.87 & 0.75 & 1.49 & 3.45 & 3.43 \\
\hline F3 & 2.84 & 1.50 & 0.087 & 0.082 & 0.24 & 0.61 & 0.55 & 0.88 & 0.95 & 1.52 & 3.85 & 3.69 \\
\hline F4 & 2.97 & 1.48 & 0.099 & 0.081 & 0.27 & 0.59 & 0.76 & 0.88 & 1.32 & 1.52 & 4.72 & 3.49 \\
\hline $\operatorname{LSD}(\mathrm{P} \leq 0.05)$ & NS & NS & 0.005 & NS & 0.03 & NS & 0.06 & NS & 0.13 & $\mathrm{NS}$ & 0.41 & NS \\
\hline
\end{tabular}

$\mathrm{NS}=$ Not significant, $\mathrm{F} 1=0 \mathrm{~kg} \mathrm{ha}^{-1}, \mathrm{~F} 2=50 \mathrm{~kg} \mathrm{ha}^{-1}, \mathrm{~F} 3=100 \mathrm{~kg} \mathrm{ha}^{-1}, \mathrm{~F} 4=150 \mathrm{~kg} \mathrm{ha}^{-1}, \mathrm{~V} 1=$ jigida, V2 $=$ NCRIBEN-01M, V3 = NCRIBEN032 


\section{Table 9c: Main Effects of Varieties and Fertilizer Application on Selected Soil Properties in 2019}

\begin{tabular}{|c|c|c|c|c|c|c|c|c|}
\hline \multirow[t]{2}{*}{ Varieties } & \multicolumn{2}{|c|}{$\mathrm{pH}$} & \multicolumn{2}{|c|}{$\begin{array}{l}\text { Sand } \\
(\%)\end{array}$} & \multicolumn{2}{|c|}{$\begin{array}{l}\text { Clay } \\
(\%)\end{array}$} & \multicolumn{2}{|c|}{$\begin{array}{l}\text { Silt } \\
(\%)\end{array}$} \\
\hline & Makurdi & Potiskum & Makurdi & Potiskum & Makurdi & Potiskum & Makurdi & Potiskum \\
\hline V1 & 6.32 & 6.61 & 69.48 & 71.50 & 18.99 & 15.37 & 11.81 & 13.13 \\
\hline V2 & 6.30 & 6.57 & 69.30 & 71.10 & 18.56 & 15.51 & 12.14 & 13.39 \\
\hline V3 & 6.32 & 6.57 & 69.23 & 71.84 & 18.69 & 14.95 & 12.08 & 13.21 \\
\hline $\operatorname{LSD}(\mathrm{P} \leq 0.05)$ & $\mathrm{NS}$ & NS & $\mathrm{NS}$ & NS & NS & $\mathrm{NS}$ & NS & NS \\
\hline \multicolumn{9}{|l|}{ Fertilizer } \\
\hline $\mathrm{F} 1$ & 6.57 & 6.55 & 69.18 & 71.52 & 19.82 & 15.17 & 11.00 & 13.31 \\
\hline $\mathrm{F} 2$ & 6.18 & 6.60 & 69.56 & 71.26 & 17.96 & 15.49 & 12.48 & 13.26 \\
\hline $\mathrm{F} 3$ & 6.29 & 6.59 & 70.49 & 71.52 & 16.98 & 15.26 & 12.90 & 13.22 \\
\hline $\mathrm{F} 4$ & 6.23 & 6.59 & 68.13 & 71.62 & 20.22 & 15.19 & 11.65 & 13.19 \\
\hline $\operatorname{LSD}(\mathrm{P} \leq 0.05)$ & 0.18 & $\mathrm{NS}$ & NS & NS & 0.77 & NS & NS & NS \\
\hline
\end{tabular}

$\mathrm{NS}=$ Not significant, F1 $=0 \mathrm{~kg} \mathrm{ha}^{-1}, \mathrm{~F} 2=50 \mathrm{~kg} \mathrm{ha}^{-1}, \mathrm{~F} 3=100 \mathrm{~kg} \mathrm{ha}^{-1}, \mathrm{~F} 4=150 \mathrm{~kg} \mathrm{ha}^{-1}$,

$\mathrm{V} 1=$ jigida, $\mathrm{V} 2=\mathrm{NCRIBEN}-01 \mathrm{M}, \mathrm{V} 3=\mathrm{NCRIBEN}-032$ 


\section{CONCLUSION AND RECOMMENDATIONS}

Based on the findings of this study, the improved varieties performed better than the local variety in terms of yield at both locations. In 2019, the highest yields in Makurdi and Potiskum were obtained with NCRIBEN-032. All the varieties performed better in 2018 than 2019 at both locations. The effects of varieties on soil properties did not differ significantly. However, the improved varieties left lower essential nutrients in soil and the local variety gave higher values in soil properties after harvest. The effect of the year of planting did not influence yield significantly in both cropping seasons. The effects of the planting on soil properties indicated that the soil properties were higher in 2018 in Makurdi but higher in 2019 in Potiskum. The effect of location indicated that Potiskum yield in 2018 was higher than that of Makurdi. Similar yield results were obtained in 2019 for both locations. Location effect showed that the Potiskum soil had more nutrients than that of Makurdi. Fertilizer application at $150 \mathrm{~kg} \mathrm{ha}^{-1}$ of NPK 15:15:15 favoured the retention of organic matter as well as other essential nutrient elements in soil and is hereby recommended for sustainable sesame production in both locations.

\section{REFERENCES}

Adebowale, A. A., Sanni, S. A. and Falore, O. A. (2010). Varietal differences in the physical properties and proximate composition of elite sesame seeds. Libyan Agricultural Research Center Journal International 1 (2): 103-107.

Adekayode, F. O. and Ogunkoya, M. O. (2010). Effect of quantity and placement distances of inorganic 15-15-15 fertilizer in improving soil fertility status and the performance and yield of maize in Tropical Rain Forest Zone of Nigeria. American-Eurasian J. Agric \& Environmental Sci., 7 (2): 122-129.

Adekiya, A. O., Agbede, T. M., Ojomo, A. O. (2009). Effect of tillage methods on soil properties, nutrient contents, growth and yield of tomato on an Alfi sol of southwestern Nigeria. American-Eurasian Journal of Sustainable Agriculture 3(3): 348-353.

Aduayi, E. A., Chude, V. O., Adebusuyi, B. A. and Olayiwola, S. O. eds. (2002). Fertilizer Use and Management Practices for Crops in Nigeria. $3^{\text {rd }}$ ed. Garko international limited. 67-70.

Agbede, O. O. (2009). Understanding Soil and Plant Nutrition. Lafia: Salman Press. $2^{\text {nd }}$ Edition. Pp. 42-66.

Agbede, T. M., Adekiya, A. O. and Ogeh, J. S. (2013). Effects of organic fertilizers on yam productivity and some soil properties of a nutrient-depleted tropical Alfisol. Archives of Agronomy and Soil Science, 59:803-822.

Agber, P. I., Ter, S. and Ayuba, S. A. (2012). Assessment of pearl millet performance to early and late planting opportunities and fertilizer application models in Makurdi, Nigeria. African Journal of Agricultural Research, 7(44):5955-5961.

Akinoso, R., Aboaba, S. A. and Olayanju, T. M. A. (2010). Effects of moisture content and heat treatment on peroxide value and oxidative stability of un-refined sesame oil. AJFAND, 10 (10): 4268- 42850.

Ali, A., Ayuba, S. A. and Ojeniyi, S. O. (2006). Effect of tillage and fertilizer on soil chemical properties, leaf nutrient content and yield of soybean in the guinea savanna zone of Nigeria. Nigerian Journal of Soil Science. 16:126-135. 
Anjembe, B. C. (2004). Evaluation of Sulphur Status for Groundnut Production in Some Selected Soils of Benue State, Nigeria. M.Sc Thesis. University of Agriculture, Abeokuta, Nigeria.70 Pp.

Ayoola, O. T. (2006). Effects of fertilizer treatments on soil chemical properties and crop yields in a cassava-based cropping system. Journal of Applied Sciences Research, 2(12): 1112-1116.

Babbu, S. B., Jagdeep, S., Gurbir, S. and Gurpreet, K. (2015). Effects of long term application of inorganic and organic fertilizers on soil organic carbon and physical properties in maize-wheat rotation. Agronomy Journal, 5, 220-238.

Babeji, B. A., Ali, R. I., Yahaya, R. A., Mahadi, M. A. and Sharifari, A. I. (2006). Nitrogen and phosphorus nutrition of sesame at Samar Nigeria. Proceedings of 31st Annual Conference of the Soil Science Society of Nigeria (SSSN), Nov. 13 ${ }^{\text {th }}-17$ th, 2006, Ahmadu Bello University, Zaria, Nigeria.

Bennet, M. (2011). Sesame seed: A Handbook for Farmers and Investors. 29/08/11.Available at www.agmrc.org/media/cm/sesame 38F4324EE52CB.pdf

Biswas, T. K., Sana, N. K., Badal, R. K. and Haque, E. M. (2001). Biochemical study of some oil Seeds (Brassica, Sesame \& Linseed). Pakistan Journal of Biological Sciences 4:1002-1005.

Bonsu, O. K. (2003). The effect of spacing and fertilizer application on the growth, yield and yield components of sesame (Sesamum indicum L.). J. Sust.Agric., 23 (1): 40-49.

Bouyocous, G.H. (1951). A Recalibration of the Hydrometer Method for making the Mechanical Analysis. Agronomy Journal. 43: 434-438.

Bray, R. H. and Kurtz, L. T. (1945). Determination of total organic and available forms of phosphorus in soils. Soil Science. 59: 39-45.

Bremner, J.M. and Mulraney, C.S. (1982). Nitrogen Total In: Methods of Soil Analysis $2^{\text {nd }}$ ed. A.L. Page et al., (Eds) ASA, SSSA Medison Winsconsin. Pp. 595-624.

Chude, V. O., Olayiwola, S. O., Daudu, C., Ekeoma, A. (2012). Fertilizer Use and Management Practices for Crops in Nigeria. 4th edition Federal Fertilizer Department, Federal Ministry of Agriculture and Rural Development. Abuja. Pp.224

Eifediyi, E. K., Ahamefule, H. E., Ojiekpon, I. F., Agbede, T. M., Remison, S. U., Aliyu, T. H., Olukayode, T. O. and Bangura, A. K. (2016). Response of sesame (Sesamum indicum L.) to mulching and inorganic fertilizer application in a Southern Guinea Savanna Zone of Nigeria. Agriculture \& Forestry, 6(2): 201-216.

Eifediyi, E. K., Komolafe, O. A., Ahamefule, H. E. and Folola, A. (2018). Effect of tillage and poultry manure rates on physiological growth and yield of sesame (Sesamum indicum L.). Plant Sciences: Scientia Agriculturae Bohemica, 49(4):255-266.

El-Nakhlawy, F. S. and Shaheen, M. A. (2009). Response of seed yield, yield components and oil content to the sesame cultivar and nitrogen fertilizer rate diversity. JKAU: Met. Env. and Arid Land Agric.Sci., 20(2): 21-31.

Esu, I. E. (1991). Detailed Soil Survey of NIHORT Farm at Bunkure Kano state, Nigeria. Institute of Agricultural Research, Zaria. Pp.72.

FAO (2009). Food and Agriculture Organization of the United Nation: The state of food and agriculture, Rome. Retrieved 2009 at http://www.fao.org/catalog/inter-e.htm

Hansen, R. (2011). Sesame profile. Retrieved on 19/08/11. Available on line at http://www.agmrc.org/commodities_products/grains_oilseeds/sesame_profile.cfm

Haynes, R. and Naidu, R. (1998). Influence of lime, fertilizer and manure applications on soil organic mattercontent and soil physical conditions: A review. Nutrient Cycle Agroecosystem, 51, 123-137. 
Ibrahim, F., Anjembe, B. and Olatunji, O. (2017). Influence of Poultry Manure on Phosphate Fertilizer Need of Soybean (Glycine max Merill $(L)$ in Some Selected Alfisols in Benue State. European Journal of Agriculture and Forestry Research, 5(3):31-40.

Iwo, G. A., Idowo, A. A. and Ochigbo, A. A. (2002). Evaluation of sesame genotypes for yield stability and selection in Nigeria. Nigerian Agricultural Journal, 33:76-82.

Jakusko, B. B. and Usman, B. D. (2013). Effect of NPK fertilizer and plant density on productivity of sesame (Sesamum indicum L.). Research Journal of Agricultural and Environmental Management, 2(5): 121-126.

Malgwi, W. B, Ojaguna, A. G Chude, V. O. Kparmwang, T. and Raji, B. A. (2008). Morphological and Physical Properties of some Soils at Samaru, Zaria, Nigeria. Nigeria Journal of Soil Research, 1: 58 - 64.

Naturland (2002). Organic farming in the Tropics and Subtropics: Sesame. 21/07/11.Available at: www.naturland.de/fileadmin/MDB/documents/Publication/English/sesame.pdf

NCRI (2002). Guide to beniseed (sesame) production. Oilseed Research Program. NCRI, Badeggi. Pp.4-5.

Nigeria's Harvest (2009). Small seed provides large income. Vol. 5, No 21.Retrieved on 21/10/09. Available on line at http://www.nigeriamarkets.org/files/Nigeria\%27s_Harvest_Exporting_Nigerian_Sesa $\underline{\text { me.pdf }}$

Odunze A. C. (2006). Soil properties and management strategies for some sub humid Savanna zone Alfisols in Kaduna State, Nigeria. Samaru Journal Agriculture Research. 22:3-14.

Ojeniyi, S. O., Ibrahim, N. B. and Iorlamen, T. (2016). The effects of different types of fertilizers on the growth and yield of sesame (Sesamum indicum $\mathrm{L}_{.}$) in Makurdi. Nigerian Journal of Soil Science. 26: 272-278.

Olatunji, O., Ali, A. and Ibrahim, N. B. (2014). Tolerance of cowpea (Vigna unguiculata (L) varieties N- fixing ability to application of cow dung combined with NPK 20-10-10. IOSR Journal of Agriculture and Veterinary Science, 7(1):93-100.

Onwudiwe, N., Benedict, O. U., Ogbonna, P. E. and Ejiofor, E. E. (2014).Municipal solid waste and NPK fertilizer effects on soil physical properties and maize performance in Nsukka, Southeast Nigeria. African Journal of Biotechnology, 13(1): 68-75.

Senjobi, B. A., Ande, O. T. and Okulaja, A. E. (2013). Effects of tillage practices on soil properties under maize-cultivation on Oxic paleustalf in South Western Nigeria. Open journal of Soil Science, 3: 163-168.

Shangakkara, W. R. M., Liedgens, Soldall, A. and Stamp, P. (2004). Root and shoot growth of maize (Zea mays L.) as affected by incorporation of Crotalaria, Juncea and Tithonia diversifolia as green manure. Journal of Agronomy and Crop Science, 190: 139-146.

Srivastava, A. K., Goering, C. E., Rohrbach, R. P. And Buckmaster, D. R. (2006). Engineering Principles of Agricultural Machines, (2nd edn), American Society of Agricultural and Biological Engineers, Michigan.

USAID (2002). Overview of the Nigerian sesame industry. Washington DC: Chemonic International Inc. Pp. 20-50.

YSGN (2008). Yobe State Ministry of Information; 2008. Available: http://zodml.org/Nigeria/Geography/Yobe State/ 